\title{
Publisher Correction: Sumatran tiger survival threatened by deforestation despite increasing densities in parks
}

\author{
Matthew Scott Luskin (10) 1,2,3, Wido Rizki Albert ${ }^{4}$ \& Mathias W. Tobler ${ }^{5}$
}

Correction to: Nature Communications https://doi.org/10.1038/s41467-017-01656-4, published online 05 December 2017

In the original version of the Article, reference 18 was incorrectly numbered as reference 30, and references 19 to 30 were incorrectly numbered as 18 to 29. These errors have now been corrected in the PDF and HTML versions of the manuscript.

Published online: 12 February 2018

\begin{abstract}
(c) Open Access This article is licensed under a Creative Commons Attribution 4.0 International License, which permits use, sharing, adaptation, distribution and reproduction in any medium or format, as long as you give appropriate credit to the original author(s) and the source, provide a link to the Creative Commons license, and indicate if changes were made. The images or other third party material in this article are included in the article's Creative Commons license, unless indicated otherwise in a credit line to the material. If material is not included in the article's Creative Commons license and your intended use is not permitted by statutory regulation or exceeds the permitted use, you will need to obtain permission directly from the copyright holder. To view a copy of this license, visit http://creativecommons.org/licenses/by/4.0/.
\end{abstract}

(C) The Author(s) 2018

\footnotetext{
${ }^{1}$ Center for Tropical Forest Science - Forest Global Earth Observatory, Smithsonian Tropical Research Institute, PO Box 37012, Washington, DC 20012, USA

${ }^{2}$ Asian School of the Environment, Nanyang Technical University, 50 Nanyang Avenue, N2-01c-36, Singapore 639798, Singapore. ${ }^{3}$ Department of Environmental Science, Policy, and Management, University of California, Berkeley, 204 Mulford Hall, Berkeley, CA 94720, USA. ${ }^{4}$ Fauna \& Flora International - Indonesia Programme, PO Box 42, Sungai Penuh, Kerinci, Jambi, 37111 Sumatra, Indonesia. ${ }^{5}$ San Diego Zoo Global, Institute for Conservation Research, 15600 San Pasqual Valley Road, Escondido, CA 92027-7000, USA Correspondence and requests for materials should be addressed to

M.S.L. (email: mattluskin@gmail.com)
} 